\title{
Feeding conditions modify the photoperiodically induced dispersal of the water strider, Aquarius paludum (Heteroptera: Gerridae)
}

\author{
TETSUO HARADA and TATSUYA NISHIMOTO \\ Laboratory of Environmental Physiology, Faculty of Education, Kochi University, Kochi 780-8520, Japan; \\ e-mail: haratets@cc.kochi-u.ac.jp
}

Key words. Gerridae, photoperiodism, food condition, oogenesis-flight syndrome, flight muscle histolysis, Aquarius paludum

\begin{abstract}
Overwintering adults of the water strider, Aquarius paludum were collected from the field in fall and kept under short days $(12 \mathrm{~L}: 12 \mathrm{D})$ at $20^{\circ} \mathrm{C}$ for a week. A control group was then kept at $12 \mathrm{~L}: 12 \mathrm{D}$ and fed daily, and three experimental groups were transferred to $15.5 \mathrm{~L}: 8.5 \mathrm{D}$ and fed at different frequencies: daily or every 2 nd or 3rd day. Temperature was kept at $20^{\circ} \mathrm{C}$. Flight behaviour of the adults in the four groups was recorded every 10 days up to the end of the 5th week when the adults were dissected. State of the flight muscles and reproductive organs (ovaries and testes) was recorded. Flight ability of the adults fed every 3 rd day (Group 3) was higher than that of those fed daily (Group 1). Seventy percent of the females that were fed every 3rd day (Group 3) remained in diapause for 5 weeks, in spite of the reproduction promoting long-days, while none of the females fed every day remained in diapause (Group 1). Flight muscle histolysis, promoted by long-days, was inhibited by poor feeding conditions. Thus, they can migrate and seek more suitable water bodies rich in food. The modifying effect of the availability of food on the trade-off between reproduction and flight is recorded here for the first time for a carnivorous insect.
\end{abstract}

\section{INTRODUCTION}

Control of diapause induction or diapause development may be achieved by integrating photoperiod and food conditions in some insects, including carnivorous insects. Lack of prey or reduced access to prey enhances diapause induction even under "long-days", which promote reproduction in the lacewing, Chrysopa carnea (Tauber \& Tauber, 1973, 1982) and ladybird, Semiadalia undecimnotata (Iperti \& Hodek, 1974; Rolley et al., 1974).

Several water striders which inhabit fresh water, use photoperiod to regulate their reproductive and dispersal characteristics, including wing length and flight muscle maturation (Spence \& Andersen, 1994; Harada et al., 2000, 2005). In the water strider, Aquarius paludum, for example, photoperiod is the main environmental factor regulating several life history traits such as reproduction, wing length, flight muscle condition, flight ability, and resistances to high and low temperatures and drying-out (Harada, 2003a, b). Long days inhibit flight activity and promote flight muscle histolysis (Inoue \& Harada, 1997; Harada et al., 2000). Long days promote reproduction, whereas short days induce reproductive diapause or the maturation of flight muscles and flight in A. paludum (Inoue \& Harada 1997; Harada et al., 2000). Increasing photoperiod, even when shorter than the critical photoperiod for diapause induction, can inhibit flight and promote the histolysis of flight muscles (Inoue \& Harada, 1997). As a result of this photoperiodic response, nutritional resources are allocated to reproduction in summer and dispersal to and from overwintering sites in autumn and spring. That is, A. paludum shows the so-called "oogenesis flight syndrome" (Johnson, 1969; Harrison, 1980). However, there is no information on whether food availability can modify the photoperiodic control of the trade-off between fllight and reproduction in A. paludum. This paper reports the results of a laboratory experiment designed to test this idea.

\section{MATERIAL AND METHODS}

\section{Material and rearing conditions}

Adults of the water strider, Aquarius paludum (Fabricius) which were in reproductive diapause, were collected from two rivers in Kochi $\left(33^{\circ} \mathrm{N}\right)$ at the beginning of October, 2003. They were exposed to a low temperature of $7^{\circ} \mathrm{C}$ for 2 days to promote the development of flight muscles (Harada et al., 2003) and then kept under conditions of $12 \mathrm{~h}$ light $-12 \mathrm{~h}$ dark (12L : 12D) and $20 \pm 2{ }^{\circ} \mathrm{C}$ for a week, which are similar to those prevailing in the field in late fall at Kochi. Then, they were transferred to one of the following 4 conditions, and kept at $20 \pm 2{ }^{\circ} \mathrm{C}$.

Group 1: Fed every day, 15.5L : 8.5D,

Group 2: Fed every two days, $15.5 \mathrm{~L}: 8.5 \mathrm{D}$,

Group 3: Fed every three days, $15.5 \mathrm{~L}: 8.5 \mathrm{D}$,

Group 4: Fed every day, 12L : 12D.

Each pair of water striders was fed one adult fly of Lucilia illustris per day etc. Each group included 22 pairs of females and males, and all individuals survived for 5 weeks. Flight ability was determined every 10 days after transfer up to the end of the fifth week, when the adults were dissected. Condition of the flight muscles and reproductive organs (ovaries and testes) were observed and recorded.

\section{Flight experiment}

Flight ability was determined using the method of Harada et al. (1997). A piece of white paper was placed on the bottom of a large transparent cylinder ( $30 \mathrm{~cm}$ in diameter and $15 \mathrm{~cm}$ height), and an adult water strider was transferred from its rearing cage into a small transparent cylinder (5 $\mathrm{cm}$ in diameter), which was placed at the center of the piece of paper at the bottom of the large cylinder. Infra-red light warmed the bottom of the large cylinder to a temperature of $32 \pm 2{ }^{\circ} \mathrm{C}$. The individual insects 
TABLE 1. Influence of food supply on the proportion of individuals of the water strider, Aquarius paludum that showed wingopening or flight, and results of $\chi^{2}$-test of the differences among the 4 experimental groups.

\begin{tabular}{|c|c|c|c|c|c|c|}
\hline \multirow{2}{*}{ Condition } & \multicolumn{6}{|c|}{ Proportion of individuals showing wing-opening or flight activity (\%) } \\
\hline & $0 \mathrm{~W}$ & $1 \mathrm{~W}$ & $2 \mathrm{~W}$ & $3 \mathrm{~W}$ & $4 \mathrm{~W}$ & $5 \mathrm{~W}$ \\
\hline \multicolumn{7}{|c|}{ Fed every day, $15.5 \mathrm{~L}: 8.5 \mathrm{D}$} \\
\hline Males & $72.7(22)$ & $72.7(22)$ & $45.5(22)$ & $45.5(22)$ & $15.0(20)$ & $5.0(20)$ \\
\hline Females & $68.2(22)$ & $63.6(22)$ & $36.4(22)$ & $36.3(22)$ & $4.5(22)$ & $9.0(22)$ \\
\hline \multicolumn{7}{|c|}{ Fed every 2 days, $15.5 \mathrm{~L}: 8.5 \mathrm{D}$} \\
\hline Males & $90.1(22)$ & $81.8(22)$ & $77.3(22)$ & $63.6(22)$ & $47.6(21)$ & $42.9(21)$ \\
\hline Females & $72.7(22)$ & $90.9(22)$ & $81.0(21)$ & $60.0(20)$ & $35.0(20)$ & $26.3(19)$ \\
\hline \multicolumn{7}{|c|}{ Fed every three days, $15.5 \mathrm{~L}: 8.5 \mathrm{D}$} \\
\hline Males & $59.1(22)$ & $59.1(22)$ & $50.0(22)$ & $50.0(22)$ & $33.3(21)$ & $28.6(21)$ \\
\hline Females & $72.7(22)$ & $59.1(22)$ & $63.6(22)$ & $63.6(22)$ & $50.0(22)$ & $36.4(22)$ \\
\hline \multicolumn{7}{|c|}{ Fed every day, 12L : 12D } \\
\hline Males & $72.7(22)$ & $77.3(22)$ & $72.7(22)$ & $77.3(22)$ & $77.3(22)$ & $36.4(22)$ \\
\hline Females & $90.9(22)$ & $86.4(22)$ & $95.5(22)$ & $90.5(21)$ & $85.7(21)$ & $66.7(21)$ \\
\hline \multicolumn{7}{|l|}{$\chi^{2}$ test } \\
\hline$\chi^{2}$ value & 4.61 & 10.71 & 23.35 & 17.08 & 44.9 & 25.12 \\
\hline $\mathrm{df}$ & 3 & 3 & 3 & 3 & 3 & 3 \\
\hline $\mathrm{P}$ & 0.203 & 0.013 & $<0.001$ & $<0.001$ & $<0.001$ & $<0.001$ \\
\hline
\end{tabular}

$\mathrm{W}=$ weeks.

were then illuminated from the side for $30 \mathrm{~s}$ using a beam of blue light (about $3400 \mathrm{Lx}$ ) produced by passing the light from a tungsten lamp through a glassy filter. Administered together, the heat and blue light triggered flight in individuals that were able to fly. The enclosure was then removed and the bug observed for $1 \mathrm{~min}$. After the first observation the bug was again stimulated by exposing it to blue light and observed for an additional minute. Most of the bugs that flew did so for less than $0.5 \mathrm{~s}$ and then folded their wings. Flight ability of each insect is indicated by the flight index (FI), which was calculated as follows: Each bug was observed for $3 \mathrm{~min}$, and each wing-opening recorded during this period was assigned " +1 " and each flight " +2 " and FI was the total of those observations, i.e. FI $=$ (number of wing-openings) $+2 \mathrm{x}$ (number of flights).

\section{Indices of flight muscle development and testis volume}

Flight muscle maturation was ranked in one of three grades, according to the criterion proposed by Harada et al. (1997). This is a simplified version of the criterion used by Fairbairn \& Desranleau (1987): Rank 3, indirect flight muscles large, fibrous and reddish, which corresponds to "normal" of Fairbairn \& Desranleau (1987); Rank 2, flight muscles smaller, soft, white, corresponding to "teneral: advanced" or "histolysed: early"; Rank 1, muscle fibers not visible, corresponding to "histolysed: advanced or complete" or "teneral: early". The volume-index of testes which have a cylindrical shape, was defined as the average of left and right testes volumes, which were calculated using the expression: (half width) $)^{2} \pi \times$ (length) $\mathrm{mm}^{3}$.

\section{Size of fat body and presence of oil droplets in fat body}

The quantity of fat and presence of oil droplets in the fat lining the body wall were estimated as indices, based on the criteria proposed by Kishi et al. (2006).

Fat-body index

Rank 1: no fat, Rank 2: thin layer of fat, body wall visible, Rank 3: thick layer of fat, body wall not visible, Rank 4: extremely thick layer of fat, body wall not visible.
Oil droplets in fat body

Rank 1: no oil droplets, Rank 2: a few small transparent oil droplets, Rank 3: many transparent or yellowish oil droplets, Rank 4: numerous large yellow oil-droplets.

\section{Statistical analysis}

Data were analyzed statistically using SSPS 11.0 version for personal computer. Pearson's analysis, Mann-Whitney U-test, Kruskal-Wallis test and $\chi^{2}$ test were each performed in an appropriate manner.

\section{RESULTS}

\section{Flight ability and flight muscles}

Significant effects of feeding conditions were not shown on flight during the first 2 weeks (Tables 1, 2). However, after 4-5 weeks significantly more adults fed only every 3 days (Group 3) flew than those fed every day (Group 1) (Kruskal-Wallis test, $\chi^{2}=-5.262$ or $-4.473, \mathrm{P}<0.001)$. However, the individuals in Group 3 flew significantly less after 4 and 5 weeks than those kept under 12L : 12D (Mann-Whitney U-test after 4 weeks: $\mathrm{z}$ $=-3.48, \mathrm{P}=0.001 ; 5$ weeks, $\mathrm{z}=-2.40, \mathrm{P}=0.017)$. The high tendency to fly shown by females that were fed less frequently was maintained for 3 weeks, but that of males only 1 week (Table 2)

Many $(31.8 \%)$ of the adults fed only every 3 days (Group 3) had mature flight muscles of Rank 3, even 5 weeks after transferring then to long-day condition and this was higher than the $4.7 \%$ of the adults fed every day (Group 1) $\left(\chi^{2}\right.$ test, $\chi^{2}$ value $\left.=35.89, \mathrm{df}=2, \mathrm{P}<0.001\right)$ and $9.1 \%$ of those fed every 2 days (Group 2$)\left(\chi^{2}\right.$ test, $\chi^{2}$ value $=13.63, \mathrm{df}=2, \mathrm{P}=0.001)($ Table 2$)$. 
TABLE 2. Influence of food supply on the incidence of flight in the water strider, Aquarius paludum [median (quartiles)] and results of Mann-Whitney U-test of the differences between sexes in each data set.

\begin{tabular}{|c|c|c|c|c|c|c|}
\hline \multirow{2}{*}{ Condition } & \multicolumn{6}{|c|}{ Weekly change in flight-index } \\
\hline & $0 \mathrm{~W}$ & $1 \mathrm{~W}$ & $2 \mathrm{~W}$ & $3 \mathrm{~W}$ & $4 \mathrm{~W}$ & $5 \mathrm{~W}$ \\
\hline \multicolumn{7}{|c|}{ Fed every day, $15.5 \mathrm{~L}: 8.5 \mathrm{D}$} \\
\hline Males & $\begin{array}{c}5.5(0,21) \\
(22)\end{array}$ & $\begin{array}{c}4(0,7) \\
(22)\end{array}$ & $\begin{array}{c}0(0,9) \\
(22)\end{array}$ & $\begin{array}{c}0(0,5) \\
(22)\end{array}$ & $\begin{array}{c}0(0,0) \\
(19)\end{array}$ & $\begin{array}{c}0(0,0) \\
(19)\end{array}$ \\
\hline Females & $\begin{array}{c}11.5(0,18) \\
(22)\end{array}$ & $\begin{array}{c}4.5(0,7) \\
(22)\end{array}$ & $\begin{array}{c}1(0,4.5) \\
(22)\end{array}$ & $\begin{array}{c}0(0,3) \\
(22)\end{array}$ & $\begin{array}{c}0(0,0) \\
(22)\end{array}$ & $\begin{array}{c}0(0,0) \\
(22)\end{array}$ \\
\hline $\mathrm{Z}$ & -0.578 & -0.459 & -0.429 & -0.086 & -0.140 & -1.076 \\
\hline $\mathrm{P}$ & 0.563 & 0.646 & 0.668 & 0.931 & 0.889 & 0.282 \\
\hline \multicolumn{7}{|c|}{ Fed every 2 days, $15.5 \mathrm{~L}: 8.5 \mathrm{D}$} \\
\hline Males & $\begin{array}{c}18(7,27) \\
(22)\end{array}$ & $\begin{array}{c}23(11.5,35) \\
(22)\end{array}$ & $\begin{array}{c}17(0.5,29) \\
(22)\end{array}$ & $\begin{array}{c}4.5(0,13.5) \\
(22)\end{array}$ & $\begin{array}{c}1(0,6) \\
(21)\end{array}$ & $\begin{array}{c}1(0,7) \\
(21)\end{array}$ \\
\hline Females & $\begin{array}{c}11(0,29) \\
(22)\end{array}$ & $\begin{array}{c}13(3,23) \\
(22)\end{array}$ & $\begin{array}{c}15(4,18) \\
(22)\end{array}$ & $\begin{array}{c}3(0.5,12) \\
(22)\end{array}$ & $\begin{array}{c}0(0,3) \\
(22)\end{array}$ & $\begin{array}{c}0(0,2) \\
(22)\end{array}$ \\
\hline $\mathrm{Z}$ & -0.808 & -1.761 & -1.429 & -1.680 & -1.871 & -0.651 \\
\hline$P$ & 0.419 & 0.078 & 0.153 & 0.093 & 0.062 & 0.515 \\
\hline \multicolumn{7}{|c|}{ Fed every three days, $15.5 \mathrm{~L}: 8.5 \mathrm{D}$} \\
\hline Males & $\begin{array}{c}3(0,10.5) \\
(22)\end{array}$ & $\begin{array}{c}4(0,11.5) \\
(22)\end{array}$ & $\begin{array}{c}1(0,9) \\
(22)\end{array}$ & $\begin{array}{c}1(0,10) \\
(22)\end{array}$ & $\begin{array}{c}0(0,7) \\
(22)\end{array}$ & $\begin{array}{c}0(0,2) \\
(21)\end{array}$ \\
\hline Females & $\begin{array}{c}5(0,23) \\
(22)\end{array}$ & $\begin{array}{c}3(0,20) \\
(22)\end{array}$ & $\begin{array}{c}3(0,12) \\
(22)\end{array}$ & $\begin{array}{c}5.5(0,11) \\
(22)\end{array}$ & $\begin{array}{c}1(0,11) \\
(22)\end{array}$ & $\begin{array}{c}0(0,5) \\
(22)\end{array}$ \\
\hline Z & -0.320 & -0.716 & -1.834 & -1.851 & -1.706 & -1.616 \\
\hline $\mathrm{P}$ & 0.749 & 0.474 & 0.067 & 0.064 & 0.088 & 0.106 \\
\hline \multicolumn{7}{|c|}{ Fed every day, $12 \mathrm{~L}: 12 \mathrm{D}$} \\
\hline Males & $\begin{array}{c}11.5(0,27) \\
(22)\end{array}$ & $\begin{array}{c}12(2,20) \\
(22)\end{array}$ & $\begin{array}{c}15(0,17) \\
(22)\end{array}$ & $\begin{array}{c}15(1,21) \\
(22)\end{array}$ & $\begin{array}{c}5(1,15) \\
(22)\end{array}$ & $\begin{array}{c}0(0,7) \\
(22)\end{array}$ \\
\hline Females & $\begin{array}{c}15.5(7.5,29) \\
(22)\end{array}$ & $\begin{array}{c}21(3,27) \\
(22)\end{array}$ & $\begin{array}{c}19(8,27) \\
(22)\end{array}$ & $\begin{array}{c}21(12,29) \\
(22)\end{array}$ & $\begin{array}{c}14(6,22) \\
(22)\end{array}$ & $\begin{array}{c}9(1,22) \\
(22)\end{array}$ \\
\hline $\mathrm{Z}$ & -1.422 & -0.816 & -0.816 & -0.513 & -1.078 & -1.658 \\
\hline$P$ & 0.155 & 0.415 & 0.476 & 0.608 & 0.281 & 0.097 \\
\hline
\end{tabular}

\section{Reproductive status}

Average number of eggs laid per female over the 5 weeks was more than 80 when females were fed every day. However, it was less than 20 in the other three groups (Kruskal-Wallis test: $\left.\chi^{2}=-13.08, \mathrm{P}=0.004\right)$. Seventy percent of the females fed every 3 days (Group 3 ) remained in reproductive diapause, even after 5 weeks under long-days, which promote reproduction (Table 4 ), while no adults fed every day remained in reproductive diapause $\left(\chi^{2}\right.$ test, $\left.\chi^{2}=22.76, \mathrm{df}=1, \mathrm{P}<0.001\right)$. The total number of eggs produced by females fed every 2 or 3 days (Groups 2, 3) was on average 43 or 28 and smaller than the 96 eggs produced by females fed every day (Group 1) (Table 4).

Males fed every 3 days tended to have smaller testes than those fed every day (Mann-Whitney $\mathrm{U}$ test: $\mathrm{z}=$ $-4.01, \mathrm{P}<0.001)$ or every 2 days (group 2$)(\mathrm{z}=-1.91, \mathrm{P}$ $=0.056)$ (Table 4). However, testes of males fed every 3 days, and kept under long days, were larger than those of males kept under the short-days (Mann-Whitney $\mathrm{U}$ test: $\mathrm{Z}$ $=-3.50, \mathrm{P}<0.001$ ) (Table 4).

\section{Correlation between reproductive status and flight muscle maturation}

There were no significant correlations between the total number of eggs produced and condition of flight muscles

TABLE 3. Effects of food supply on the condition of the flight muscles (after 5 weeks) of the water strider, Aquarius paludum, number and (\%) and result of $\chi^{2}$ test of the differences among the 4 experimental groups.

\begin{tabular}{lccccc}
\hline \multirow{2}{*}{ Food given } & Photoperiod & \multicolumn{4}{c}{ Rank of flight muscles } \\
\cline { 3 - 5 } & & 1 & 2 & 3 & Total \\
\hline Every day & $15.5 \mathrm{~L}: 8.5 \mathrm{D}$ & $29(67.4)$ & $12(27.9)$ & $2(4.7)$ & 43 \\
Every 2 days & $15.5 \mathrm{~L}: 8.5 \mathrm{D}$ & $15(34.1)$ & $25(56.8)$ & $4(9.1)$ & 44 \\
Every 3 days & $15.5 \mathrm{~L}: 8.5 \mathrm{D}$ & $3(6.8)$ & $27(61.4)$ & $14(31.8)$ & 44 \\
Every day & $12 \mathrm{~L}: 12 \mathrm{D}$ & $5(11.4)$ & $29(65.9)$ & $10(22.7)$ & 44 \\
\hline$\chi^{2}$ test, $\mathrm{df}=6, \chi^{2} \mathrm{cal}=52.711, \mathrm{P}<0.001$ & & & \\
\hline
\end{tabular}


TABLE 4. Effect of food supply on reproductive status of females and testes volume of the water strider, Aquarius paludum after 5 weeks under each condition (mean $\pm \mathrm{SD}$ or \%) and results of non-parametric tests of differences among the 4 experimental groups.

\begin{tabular}{lcccc}
\hline Food given & Photoperiod & \% not in diapause $(\mathrm{n})$ & Total number of eggs produced & Index of testes volume $\left(\mathrm{mm}^{3}\right)(\mathrm{n})$ \\
\hline Every day & $15.5 \mathrm{~L}: 8.5 \mathrm{D}$ & $100.0(22)$ & $96.5 \pm 74.21(22)$ & $0.117 \pm 0.036(21)$ \\
Every 2 days & $15.5 \mathrm{~L}: 8.5 \mathrm{D}$ & $50.0(22)$ & $43.2 \pm 24.4(11)$ & $0.129 \pm 0.016(21)$ \\
Every 3 days & $15.5 \mathrm{~L}: 8.5 \mathrm{D}$ & $31.8(22)$ & $28.0 \pm 26.9(7)$ & $0.091 \pm 0.033(22)$ \\
Every day & $12 \mathrm{~L}: 12 \mathrm{D}$ & $4.5(22)$ & $17(1)$ & $0.053 \pm 0.014(22)$ \\
\hline & $\chi^{2}$-test & 42.82 & 8.21 & Kruskal Wallis-test \\
\hline & $\chi^{2} \mathrm{cal}$ & 3 & 2 & 3 \\
$\mathrm{df}$ & $<0.001$ & 0.015 & $<0.001$ \\
\hline
\end{tabular}

of females kept under long days (Groups 1-3) (Pearson's correlation test: $\mathrm{r}=-0.14 \sim-0.21, \mathrm{P}=0.37 \sim 0.70)$, or between the total number of eggs produced and flight ability of individuals in both Groups 1 (fed every day, $\mathrm{r}=$ -0.14 or $-0.28, \mathrm{P}=0.54$ or 0.90 ) and 2 (fed every 2 days, $\mathrm{r}=0.01 \sim-0.17, \mathrm{P}=0.63 \sim 0.98)$.

However, there were significant negative correlations between the flight index and testes volume in males fed every 3 days (Group 3) (after three: $\mathrm{r}=-0.64, \mathrm{P}=0.001$; four: $\mathrm{r}=-0.59, \mathrm{P}=0.004$; and five weeks: $\mathrm{r}=-0.53, \mathrm{P}=$ 0.01 ), but not for individuals in Group 1 (fed everyday, $\mathrm{r}$ $=-0.15 \sim 0.20, \mathrm{P}=0.42 \sim 0.51$ ), Group 2 (fed every 2 days, $\mathrm{r}=0.09 \sim 0.11, \mathrm{P}=0.64 \sim 0.96$ ) or Group 4 (kept under the short days, $\mathrm{r}=0.01 \sim 0.17, \mathrm{P}=0.45 \sim 0.97$ ).

\section{Size of fat body and presence of oil droplets in fat body}

Food supply and photoperiod had no effect on the quantity of fat-body lining the body wall (Table 5). However, there were fewer oil droplets in the fat body of females fed every 3 days (Group 3) than of those in the other three groups (Table 5).

\section{DISCUSSION}

\section{Trade-off between reproduction and dispersal characteristics}

Strong support for an adaptive trade-off between flight ability and reproduction is provided by comparative studies of wing-polymorphic insects belonging to several orders (Denno et al., 1989; Roff \& Fairbairn, 1991; Zera \& Denno, 1997). Long-winged forms are significantly less fecund than flightless forms in grasshoppers (Ritchie et al., 1987), crickets (Mole \& Zera, 1993; Tanaka \& Suzuki, 1998), planthoppers (Denno et al., 1989), aphids (Dixon \& Howard, 1986), seed bugs (Solbreck, 1986), water striders and veliids (Zera, 1984; Muraji \& Nakasuji, 1988; Harada, 1992).

\section{Response to a low food supply}

Even the long-winged adults of the water strider, Aquarius paludum, can reproduce in spring after migrating to water bodies from overwintering sites on land (Harada, 1993). The trade-off between flights and reproduction is modified by availability of food. The response to a food shortage depends upon whether the females are on a water surface or not. When water bodies dry out, food shortage promotes the histolysis of flight muscles, and nutritional resources derived from the histolyzed flight muscles enable them to survive until it rains (Harada, 1998). However, when adults on water bodies suffer a food shortage, they retain the ability to fly (Tables 1,2) and do not histolyse their flight muscles (Table 3). Mechanical stimuli from the substrate (water or land) induce the switch to dispersal; females respond to a shortage of food by adopting " flight" strategy.

TABLE 5. Effect of food supply on size of fat-body and Rank-number of oil-droplets in fat-body (after 5 weeks) of the water strider, Aquarius paludum, and results of $\chi^{2}$ testing of differences in the combined data for both sexes among the 4 experimental groups.

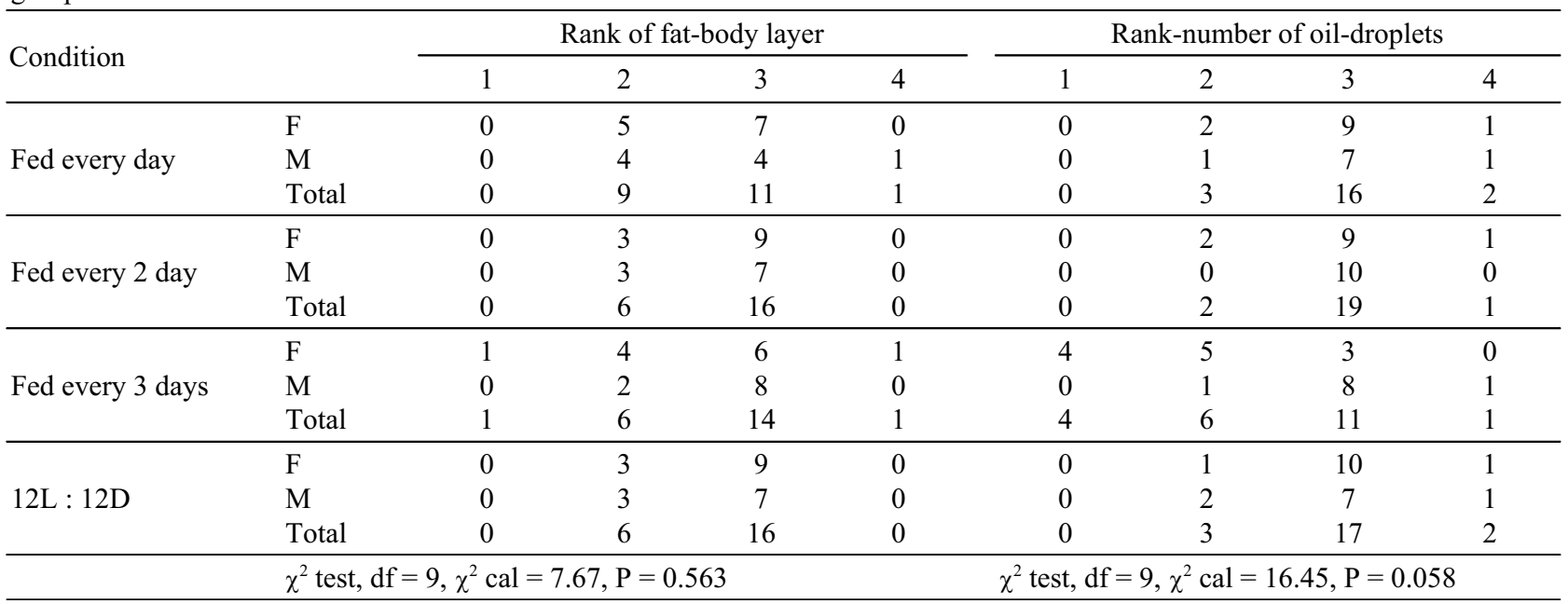


The store of fuel in fat body, especially oil droplets are used by the females of $A$. paludum, which mature their flight muscles when short of food (Table 5). Females retain their flight ability for longer than males when starved. Females arriving by chance at a water body, where the feeding conditions are poor, retain their flight ability and seek out food-rich water bodies, utilizing the fuel in their fat bodies, particularly the oil droplets. For a better understanding of the effect of poor nutrition on flight ability, further experiments are needed using individuals that have overwintered or belong to the 1 st or 2 nd generation, which are present in early spring and summer.

In conclusion, flight muscle histolysis promoted by long-days is inhibited by poor feeding conditions in $A$. paludum. The modifying effect of food supply on the trade-off between reproduction and flight, which is regulated by photoperiod, is reported here for the first time in a carnivorous insect.

\section{REFERENCES}

Denno R.F., Olmstead K.L. \& McCloud E.S. 1989: Reproductive cost of flight capability: a comparison of life history traits in wing dimorphic planthoppers. Ecol. Entomol. 14: 31-44.

Dixon A.F.G. \& HowARD M.T. 1986: Dispersal in aphids, a problem in resource allocation. In Danthanarayana W. (ed.): Dispersal and Migration. Springer, Heidelberg, pp. 145-151.

FAIRBAIRN D.J. \& DESRANLEAU L. 1987: Flight threshold, wing muscle histolysis, and alary polymorphism: correlated traits for dispersal tendency in the Gerridae. Ecol. Entomol. 12: 13-24.

HARADA T. 1992: The oviposition process in two direct breeding generations in a water strider, Aquarius paludum (Fabricius). J. Insect Physiol. 38: 687-692.

HARADA T. 1993: Reproduction by overwintering adults of water strider, Aquarius paludum (Fabricius) Zool. Sci. 10: 313-319.

HARADA T. 1998: To fly or not to fly: response of water striders to drying out of habitat. Ecol. Entomol. 23: 370-376.

HARADA T. 2003a: Hardiness to low temperature and drought in a water strider, Aquarius paludum in comparison with other insect groups. Trends Entomol. 3: 29-41.

HARADA T. 2003b: Comparative study of diapause regulation and life hitstory traits among the four species of the water striders, Aquarius paludum, Gerris latiabdominis, G. nepalensis and G. gracilicornis. Rec. Res. Devel. Entomol. 4: 77-98.

Harada T., TABUCHI R. \& Koura J. 1997: Migratory syndrome in the water strider, Aquarius paludum (Heteroptera: Gerridae) reared in high versus low nymphal densities. Eur. J. Entomol. 94: 445-452.

Harada T., Inoue T., Ono I., Doi K., Kawamura N., Kishi M., InOUE S. \& HoDKovÁ M. 2000: Endocrine, ecophysiological and ecological aspects of seasonal adaptations in a water strider, Aquarius paludum (a mini review). Entomol. Sci. 3: $157-165$.

Harada T., Inoue S. \& Watanabe M. 2003: Effects of low temperature on the condition of flight muscles and flight propensity in a water strider, Aquarius paludum (Heteroptera: Gerridae). Eur. J. Entomol. 10: 481-484.

Harada T., NitTa S. \& Ito K. 2005: Photoperiodism changes according to global warming in wing-form determination and diapause induction of a water strider, Aquarius paludum (Heteroptera: Gerridae). Appl. Entomol. Zool. 40: 461-466.

Harrison R.G. 1980: Dispersal polymorphism in insects. Annu. Rev. Ecol. Syst. 11: 95-118.

INOUE T. \& HARADA T. 1997: Lengthening photophase reduces dispersal ability in a water strider, Aquarius paludum (F.). Naturwissenschaften 84: 306-308.

IPERTI G. \& HoDEK I. 1974: Induction allimentaire de la dormance imaginale chez Semiadalia undecimnotata Schn. (Coleop. Coccinellidae) pour aider à la conservation des coccinelles élevées au laboratoire avant une utilisation ultérieure. Ann. Zool. Ecol. Anim. 6: 41-51.

Johnson C.G. 1969: Migration and Dispersal of Insects by Flight. Methuen, London, pp. 9-10.

Kishi M., FujISAKI K. \& HaradA T. 2006: How do water striders, Aquarius paludum, react to brackish water simulated by $\mathrm{NaCl}$ solutions? Naturwissenschaften 93: 33-37.

Mole S. \& Zera A.J. 1993: Differential allocation of resources underlies the dispersal-reproduction trade-off in the wingdimorphic cricket, Gryllus rubens. Oecologia 93: 121-127.

Muraji M. \& Nakasuji F. 1988: Comparative studies on life history traits of three wing dimorphic water bugs, Microvelia spp. Westwood (Heteroptera: Veliidae). Popul. Ecol. 30: 315-327.

Ritchie M.G., Butlin R.K. \& Hewitt G.M. 1987: Causation, fitness effects and morphology of macropterism in Chlorthippus parallelus (Orthoptera: Acrididae). Ecol. Entomol. 12: 209-218.

RofF D.A. \& FAIrbairn D.J. 1991: Wing dimorphisms and the ecolution of migratory polymorphisms among the Insecta. Am. Zool. 31: 243-251.

Rolley F., Hodek I. \& Iperti G. 1974: Influence de la nourriture aphidienne (selon l'âge de la plante-hôte à partir de laquelle les pucerons se multiplient) sur l'induction de la dormance chez Semiadalia undecimnotata Sch. (Coleoptera: Coccinellidae). Ann. Zool. Ecol. Anim. 6: 53-60.

Solbreck C. 1986: Wing and flight muscle polymorphism in a lygaeid bug, Horvathiolus gibbicollis: determinants and life history conseqauences. Ecol. Entomol. 11: 435-444.

SPENCE J.R. \& ANDERSEN N.M. 1994: Biology of water striders: interactions between systematics and ecology. Annu. Rev. Entomol. 39: 101-128.

TANAKA S. \& SuzUKI Y. 1998: Physiological trade-offs between reproduction, flight capability and longevity in a wing dimorphic cricket, Modicogryllus confirmatus. J. Insect Physiol. 44: 121-129.

TAuber M.J. \& TAuber C.A. 1973: Nutritional and photoperiodic control of the seasonal reproductive cycle in Chrysopa mohave (Neuroptera). J. Insect Physiol. 19: 729-736.

TAuber M.J. \& TAuber C.A. 1982: Evolution of seasonal adaptations and life history traits in Chrysopa: Response to diverse selective pressure. In Dingle H. \& Hegmann J.P. (eds): Evolution and Genetics of Life Histories. Springer, New York, pp. 51-72.

ZERA A.J. 1984: Differences in survivorship, development rate and fertility between the longwinged and wingless morphs of the waterstrider, Limnoporus canaliculatus. Evolution 38: 1023-1032.

Zera A.J. \& DenNo R.F. 1997: Physiology and ecology of dispersal polymorphism in insects. Annu. Rev. Entomol. 42: 207-231.

Received March 3, 2006; revised and accepted August 1, 2006 